\title{
INVESTIGATION OF HYGIENE INDICATORS AT CONTROL POINTS OF PILOT-SELECTED BUTCHER SHOPS
}

\author{
Beyza H. Ulusoy ${ }^{1 凶}$, Fatma Kaya Yıldırım¹, Canan Hecer², Şifa Berkan³ \\ ${ }^{1}$ Near East University, Faculty of Veterinary Medicine, Food Hygiene and Technology, Nicosia \\ ${ }^{2}$ Esenyurt Istanbul University Faculty of Health Sciences Department of Nutrition and Dietetics, \\ Istanbul, Turkey \\ ${ }^{3}$ TRNC Degirmenlik Municipality Directorate of Veterinary Affairs, Nicosia \\ «olayisim@gmail.com \\ https://doi.org/10.34302/crpjfst/2021.13.4.1 \\ Article history: \\ Received: \\ 28 July 2021 \\ Accepted: \\ 28 October 2021 \\ Keywords: \\ Butcher shop; \\ Food safety; \\ Hygiene; \\ Indicator; \\ GHP.

\begin{abstract}
In current study it was aimed to investigate hygiene indicators at control points of pilot-selected butcher shops $(\mathrm{n}=10)$ by using the conventional swabbing method and ATP Bioluminescence swabbing method. Air sampling device (Newtry ${ }^{\mathrm{TM}}$ Air sampler HAS-100B) was used for the hygiene control of the microbiological load of air in cold storage rooms. The number of yeast-mold was measured for determination microbiological load of air. For the measurement of the microbial load in food handlers' hands, staphylococci, coliform bacteria counts were investigated. In order to measure the microbiological load of the surfaces coliform bacteria and total mesophile aerobe bacteria (TMAB) counts were investigated. Surface samples were collected from 3 different points which were determined as control points. These were: 1 . cutting surfaces, 2 . knife, 3 . mincing machine. All the surfaces were mentioned as cleaned before the sampling. A scoring system was developed and good hygiene practice (GHP) status was defined for each butcher shops depending on this scoring system. The calculated scores showed us that, most of the selected butcher shops had satisfied level of GHP. The most important contamination point was found to be the cutting boards and mincing machines even they were cleaned. Air microbiological load in cold storage rooms were below the limits and hands of staffs were mostly clean in terms of coliform and $S$. aureus. We can conclude that; the
\end{abstract} \\ scoring system can be used as a tool of hygiene status monitoring.
}

\section{Introduction}

Despite the developments in food science and technology, it is still difficult to control food hazards which may potentially risks for consumers (Duffy and Schaffner, 2002). Besides other pathways of contamination, food may be contaminated especially when biological, chemical or physical agents present in the processing environment during food production processes (Da Cruz et al., 2006). With this point of view, food related illnesses because of poor infrastructure and low level of food handlers' awareness are the most important issues for many countries (Scott, 2003). Among all food groups, the animal originated foods are more likely to be hazardous in terms of pathogen content (Barril et al., 2019; EFSA and ECDC, 2016). Especially, meat and meat products are routinely associated with food poisoning outbreaks whole over the world for several years. During production, processing and storage, these products are subjected to contamination by many pathogenic bacteria (Torso et al., 2015; Barril et al., 2019). Microbiological contamination of meat and 
meat products induces meat spoilage, shortens shelf life and poses public health problems (Rao \& Ramesh, 1992). The environment in which meat production is conducted plays crucial role in determining the safety and quality of the product (Moore \& Griffith, 2002). As Barros et al., (2007) reported, the main contamination points in meat retail establishments are stainless steel boxes, beef tenderizers, grinders, knives, mixers, sausage stuffers, plastic boxes, floors and drains. Çetin et al., (2006) concluded that good hygiene practices and the implementation of sanitation standard procedures thorough cleaning of items such as cutting tables, knives and other utensils helps to reduce contamination by microbial agents in meat retails.

In general, there are many methods including microbiological, visual, physical, chemical and biochemical which can be used to assess the hygiene status of processing environments (Kymäläinen et al., 2009). Selection of the most appropriate method for microbiological analysis of surfaces can be done by the type of food produced. It is important to use the best method for isolating and detecting microorganisms (Salo et al., 2006). Control and hygiene monitoring of foods by microbiological methods offered a great deal in eliminating and/or reducing potential hazards and is viewed as essential part of quality control and food safety plans (Moore \& Griffith, 2002; LópezCampos et al., 2012). Microbiological methods, including hygiene swabbing and agar contact methods, are widely used for assessment of the cleanliness of food contact surfaces but require incubation periods of days (Vilar et al., 2008). ATP Bioluminescence methods are an attractive alternative because they provide fast and realtime assessment of surface cleanliness. Thus, ATP Bioluminescence method proved to be effective and reliable technique for monitoring sanitation and hygienic practices within the contexts of HACCP (hazard analysis critical control point) preventive systems (Chen, 2000; Ayçiçek et al., 2004; Vilar et al., 2008; PérezRodríguez et al., 2008). Although this method does not identify the quantity of microorganisms or contaminant species, it can be used as a medium for monitoring hygiene and verifying cleanliness (Calvert et al., 2000). Consequently, to monitor the efficacy of disinfection procedures, some microbiological testing (using dipslides, contact plates, swaps) may be required. ATP Bioluminescence alone should not be interpreted as surrogate indicators for the presence of microbial pathogens (Shama \& Malik, 2013). Thus, the combination of traditional culture based and luminescence methods could be applied as an integrated hygiene evaluation and monitoring strategy (Moore \& Griffith, 2002; Lehto et al., 2011).

It is imperative to detect the sources of contamination and true critical points throughout the production process in order to provide food safety (Lehto et al., 2011). With this point of view, in current study it was aimed to investigate hygiene indicators at control points of pilot-selected butcher shops $(n=10)$ by using the conventional swabbing method and ATP Bioluminescence swabbing method.

\section{Materials and methods}

\subsection{Selecting the pilot butcher shops and planning the visits}

During June-July when the highest weather temperature was the highest, 10 active working butcher shops were selected as pilot in Cyprus. In order to evaluate good hygiene practices (GHP) and good manufacturing practices (GMP), the control points where the current microbial load was expected high were determined. Pre-visits were conducted to the butchers to inform them about the visits and to define the scope of the work before the samples were collected. Selected pilot butcher shops were visited for sample collection during active work days for 4 times with 1-week interval.

\subsection{Microbiological and ATP Bioluminescence analysis}

Samples were taken from the control points which were determined during the preliminary visits. Air sampling device (Newtry $^{\mathrm{TM}}$ Air sampler HAS-100B) was used for the hygiene control of the microbiological load of air in cold storage rooms. The number of 
yeast-mold was measured for determination microbiological load of air. For the measurement of the microbial load in food handlers' hands, a sterile swab moistened with sterile physiological saline water, was used for sampling and staphylococci, coliform bacteria counts were investigated. In order to measure the microbiological load of the surfaces in contact with the food, sterile swab moistened with sterile physiological saline water was used. $10 \times 10 \mathrm{~cm}^{2}$ sized sterile plate templates were prepared in order to provide standard sampling. At the same time from the same surfaces sampling for ATP Bioluminescence measurement was performed in order to investigate organic pollution of the surfaces.
Surface samples were collected from 3 different points which were determined as control points. These were: 1. cutting surfaces, 2. knife, 3. mincing machine. All the surfaces were mentioned as cleaned before the sampling. Total mesophile aerobe bacteria (TMAB) and coliform bacteria count were investigated for those surfaces. After inoculation, incubations were carried out in the conditions as indicated in Table 1. After incubation, 30-300 colony containing petri dishes were counted and the results were reported for surfaces, hands and air as $\mathrm{CFU} / 100 \mathrm{~cm}^{2}$, CFU/hand and $\mathrm{CFU} / \mathrm{m}^{3}$, respectively.

Table 1. Media used, incubation conditions and references of methods

\begin{tabular}{|c|c|c|c|c|c|}
\hline \multirow[t]{2}{*}{ Micro-organisms } & \multirow{2}{*}{$\begin{array}{c}\text { Analytical } \\
\text { reference } \\
\text { method } \\
\end{array}$} & \multirow[t]{2}{*}{ Media name } & \multicolumn{3}{|c|}{ Incubation conditions } \\
\hline & & & $\begin{array}{c}\text { Incubation } \\
\text { temperature }\end{array}$ & $\begin{array}{c}\text { Incubation } \\
\text { period }\end{array}$ & $\begin{array}{c}\mathrm{O}_{2} \\
\text { requirement }\end{array}$ \\
\hline $\begin{array}{l}\text { Aerobic colony } \\
\text { count }\end{array}$ & ISO 4833 & $\begin{array}{l}\text { Plate Count Agar } \\
\text { (LAB 149) }\end{array}$ & $30^{\circ} \mathrm{C} \pm 1{ }^{\circ} \mathrm{C}$ & $72 \mathrm{~h} \pm 3 \mathrm{~h}$ & Aerobic \\
\hline \multirow{3}{*}{$\begin{array}{l}\text { Staphylococci } \\
\text { Staphylococcus } \\
\text { aureus }\end{array}$} & \multirow{3}{*}{$\begin{array}{l}\text { ISO } 6888- \\
1: 1999+ \\
\text { A1:2003 }\end{array}$} & $\begin{array}{l}\text { Baird Parker } \\
\text { Medium Agar (LAB } \\
085)+ \\
\text { Egg Yolk Tellurite } \\
\text { Emulsion (X 085) }\end{array}$ & $35^{\circ}-37^{\circ} \mathrm{C}$ & $24 \mathrm{~h} \pm 2 \mathrm{~h}$ & Aerobic \\
\hline & & $\begin{array}{l}\text { Brain Heart Infusion } \\
\text { Broth (LAB 049) }\end{array}$ & \multirow{2}{*}{\multicolumn{2}{|c|}{$\begin{array}{l}\text { Confirmation for } \\
\text { Staphylococcus aureus }\end{array}$}} & \\
\hline & & $\begin{array}{l}\text { Rabbit Plasma } \\
\text { (X086) }\end{array}$ & & & \\
\hline \multirow[t]{2}{*}{ Coliform bacteria } & \multirow{2}{*}{$\begin{array}{l}\text { ISO } \\
4832: 2006\end{array}$} & $\begin{array}{l}\text { Violet Red Bile } \\
\text { Glucose Agar (LAB } \\
031)\end{array}$ & $30^{\circ} \mathrm{C}-37^{\circ} \mathrm{C}$ & $24 \pm 2 \mathrm{~h}$ & Microaerophilic \\
\hline & & $\begin{array}{l}\text { Brilliant Green Bile } \\
\text { Broth (LAB051) }\end{array}$ & \multicolumn{2}{|l|}{ Confirmation } & \\
\hline Yeast and mould & $\begin{array}{l}\text { ISO 6611: } \\
2004\end{array}$ & $\begin{array}{l}\text { Yeast Glucose } \\
\text { Chloramphenicol } \\
\text { Agar (LAB 122) }\end{array}$ & $25^{\circ} \mathrm{C}$ & 5 days & Aerobic \\
\hline
\end{tabular}

For ATP Bioluminescence method, samples were collected from the defined surfaces with the help of special swabs designed for this method. $10 \times 10 \mathrm{~cm}^{2}$ sized sterile plate templates were prepared in order to provide standard sampling. The swabs were slightly moistened with sterile distilled water before the swabs were taken. After the samples were collected from the surfaces, they were placed in the ATP Bioluminescence device and the value was read. The results were given as RLU/100 $\mathrm{cm}^{2}$ unit. All the results were evaluated according to the critical limits indicated in Table 2. 
Table 2. Critical limits for microbiological and ATP Bioluminescence analyses' results

\begin{tabular}{|l|l|l|l|}
\hline Sampling points & Microorganisms & Critical limits & Reference \\
\hline $\begin{array}{l}\text { Cold storage rooms' } \\
\text { air }\end{array}$ & Mould and yeast & $1 \times 10^{3}\left(3 \log _{10}\right) \mathrm{cfu} / \mathrm{m}^{3}$ & $\begin{array}{l}\text { (Modified from) } \\
\text { Luck and Gavron, 1990 }\end{array}$ \\
\hline \multirow{2}{*}{ Staffs' hands } & Staphylococci & $1 \times 10^{2}\left(2 \log _{10}\right) \mathrm{cfu} / \mathrm{hand}$ & $\begin{array}{l}\text { (Modified from) } \\
\text { Aksu and Kaya, 2000 }\end{array}$ \\
\cline { 2 - 4 } & Coliform bacteria & $1 \times 10^{2}\left(2 \log _{10}\right) \mathrm{cfu} / \mathrm{hand}$ & $\begin{array}{l}\text { (Modified from) } \\
\text { Aksu et al., 2017 }\end{array}$ \\
\hline $\begin{array}{l}\text { Surfaces in contact } \\
\text { with food }\end{array}$ & $\begin{array}{l}\text { Aerobic colony } \\
\text { count }\end{array}$ & $1 \times 10^{2}\left(2 \log _{10}\right) \mathrm{cfu} / 100 \mathrm{~cm}^{2}$ & $\begin{array}{l}\text { (Modified from) } \\
\text { Mulvey et al., 2011 }\end{array}$ \\
\cline { 2 - 3 } & Coliform bacteria & $0\left(0 \log _{10}\right) \mathrm{cfu} / 100 \mathrm{~cm}^{2}$ & \multicolumn{2}{|c|}{} \\
\hline ATP- bioluminescence & $300 \mathrm{RLU} / 100 \mathrm{~cm}^{2}$ & & \\
\hline
\end{tabular}

\subsection{Developing scoring system according to analysis results}

A scoring system was developed and GHP status was defined for each butcher shops depending on this scoring system. For this purpose, a score value was assigned for each hygiene indicator analysis result. If the obtained results were equal or below the limits ten (10) points, if results were above the limits zero (0) point were assigned. All results were grouped under 3 headings. A percentile, based on the degree of impact on food safety, was assigned for points collected under each heading. Figure 1 demonstrates the calculating system and the analyses which were performed. Headings and percentages are as follows;

- Food Contact Surface 40\%

- Food Handlers' Hands 40\%

- Cold Storage Room $20 \%$

When all the results of a butcher were below the acceptable limits, the peak score would be 136. This point was defined as Top Point. GHP status of butchers was classified according to the points they collected. The classification was "Good" if $>68$ points, "Acceptable" if $=68$ and "Bad" if $<68$ points.

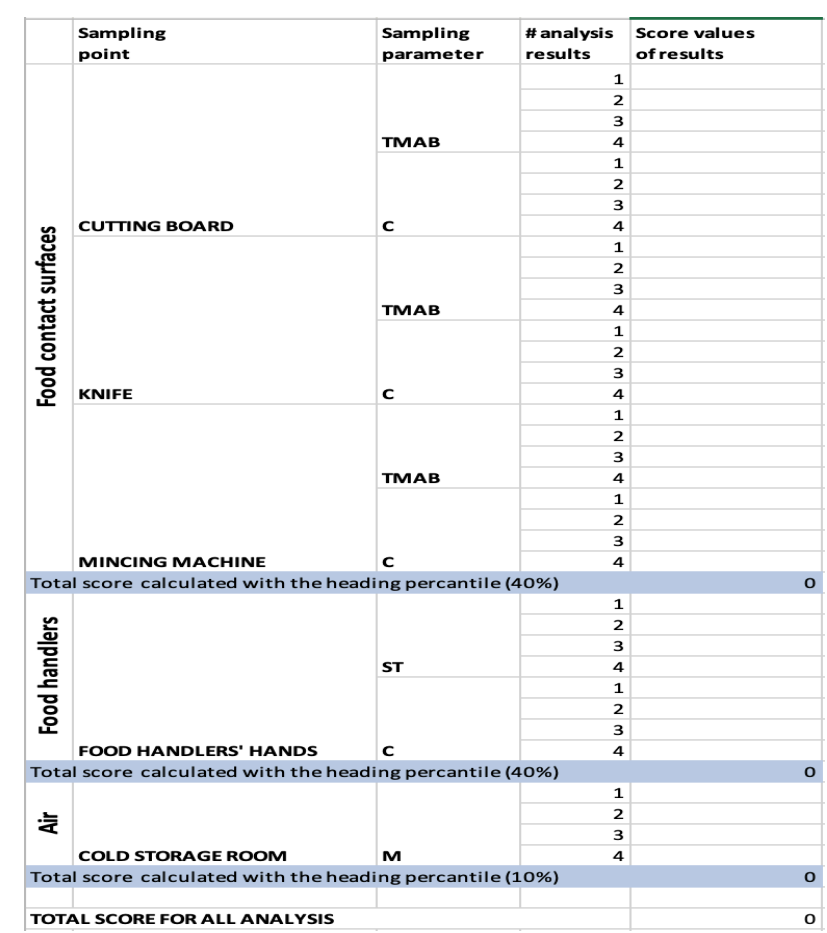

Figure 1. Calculation table scheme of GHP scoring system

\section{Results and discussions}

In current study, TMAB samples were collected from the clean surfaces of most commonly used equipment which are told to be clean. As Ghafir et al., (2008) mentioned the safety and quality of meat products can be estimated by investigating indicator microorganisms, such as aerobic mesophilic microorganisms and coliform bacteria. The number of TMAB provides an estimation for 
overall population of microorganisms regarding the hygienic conditions. Coliforms are indicators of inadequate sanitary hygienic conditions and give the possible contamination and presence of enteric pathogenic microorganisms (da Silva et al., 2016). On the other hand, the increased application of Bioluminescence based methods may be directly linked to the adoption within the food industry of a concept for systematically putting in place measures to ensure the production of foods in which all forms of potential contaminants have been reduced to acceptable levels (Shama and Malik, 2013).

In our study, when the ATP Bioluminescence results of food contact surfaces were taken into consideration, it was determined that the surfaces where the organic pollution was the highest in all butcher shops' means, were the cutting boards in 3 of 4 visits. Only for 1 visit the value was the highest for mincing machine. The values for cutting boards ranged between min $11 \mathrm{RLU} / 100 \mathrm{~cm}^{2}$ and max $48011 \mathrm{RLU} / 100 \mathrm{~cm}^{2}$. The combination of traditional culture based and luminescence methods could be applied as an integrated hygiene evaluation and monitoring strategy (Moore \& Griffith, 2002; Lehto et al., 2011). On the other hand, as Shama and Malik (2013) concluded ATP Bioluminescence alone should not be interpreted as surrogate indicators for the presence of microbial pathogens. The effectiveness of sanitation procedures has traditionally been evaluated using different methods such as visual inspection, swaps, dipslides and contact plates (Carrascosa et al., 2012; Tebbutt et al., 2007). In current study, parallel with ATP Bioluminescence results, when the TMAB counts considered as microbiological pollution indicators, the cutting boards had the highest TMAB value in all visits and ranged from min $1,6 \log _{10} \mathrm{CFU} / 100 \mathrm{~cm}^{2}$ to $\max 3,58 \log _{10} \mathrm{CFU} / 100 \mathrm{~cm}^{2}$. When the mean values of TMAB counts for all visits were evaluated according to the critical limits, all of them were over the limit $\left(2 \log _{10} \mathrm{CFU} / 100 \mathrm{~cm}^{2}\right)$. Mean values of coliform counts for cutting boards were obtained between $0,6 \quad \log _{10}$
$\mathrm{CFU} / 100 \mathrm{~cm}^{2}$ and 1,56 $\log _{10} \mathrm{CFU} / 100 \mathrm{~cm}^{2}$ (Table 3). These mean values of coliform counts for cutting boards did not meet the recommended critic limits $\left(\begin{array}{lll}0 & \log _{10}\end{array}\right.$ $\mathrm{CFU} / 100 \mathrm{~cm}^{2}$ ). Cutting boards may generally carry microbiological risk as reported in survey studies. Fidan and Ağaoğlu (2004) reported that they detected TMAB values as $6,1 \times 10^{4}(4,78$ $\left.\log _{10}\right) \mathrm{CFU} / \mathrm{cm}^{2}$ and coliform group bacterial levels as $4,1 \times 10^{3} \mathrm{MPN} / 25 \mathrm{~cm}^{2}$ in the samples taken from the restaurants' cutting surfaces in Ağrı. Those results were higher than that we obtained but the surfaces should have been completely clean as the owners told to be. In our study, mean TMAB counts of the knives were over the critical limits in 3 of 4 visits and were above the limits for meat mincing machines in all visits however they were all stated as clean. Depending on the results of coliform bacteria analyses, in 1 of 4 visits, the mean coliform counts were below the limits for knives but all were above for mincing machines. Coliform count means of mincing machines were ranged between $0,48 \log _{10} \mathrm{CFU} / 100 \mathrm{~cm}^{2}$ and $1,04 \log _{10}$ $\mathrm{CFU} / 100 \mathrm{~cm}^{2}$. On the other hand, there were negative results for knives and reached max 1,65 $\log _{10} \mathrm{CFU} / 100 \mathrm{~cm}^{2}$ in terms of coliform counts (Table 3). Similar to our results, several studies have demonstrated bacterial attachment onto stainless steel and other meat contact surface materials. Those results showed us that, mincing machines which may pose an important crosscontamination vehicle for meat, are not cleaned adequately. In the study of Garedew et al., (2016) approximately $72,2 \%$ of knives and other equipment in the butcher shops at Gondar town, Northwest Ethiopia were reported to be unsuitable in terms of hygiene. With the same study they observed that $7(10,9 \%)$ knife swabs and $8(12,5 \%)$ chopping (cutting) board swabs were positive for Shigella species. Depending on those findings they concluded that; lack of sanitary conditions is the most common cause of contamination of meat from different sources. Barril et al., (2019) determined hygienic risk of meat contact surfaces in butcher shops from Neuquén Province, Argentina. A total of 49 meat contact surfaces were sampled. According 
to their study, pathogen microorganisms were found in 28,6\% of environmental samples (Salmonella spp., 6,1\%; non-O157 STEC, 2\%; L. monocytogenes, 22,4\%). As announced in Commission Decision 2001/471/EC and Commission Regulation (EC) No 1441/2007 on Microbiological Criteria for Foodstuffs, total viable counts and total Enterobacteriaceae on cleaned and disinfected surfaces in meat establishments should be $\leq 10\left(1 \log _{10}\right) \mathrm{CFU} / \mathrm{cm}^{2}$ and $\leq 1 \quad\left(0 \log _{10}\right) \mathrm{CFU} / \mathrm{cm}^{2}$, respectively. The critical limits that we defined to compare our results are similar to these criteria (Carrascosa et al., 2012). Mincing machines can be accepted as the main contamination points for meat. In this regard Papadopoulou et al., (2012) evaluated the transfer of pathogens population from pathogen
(Listeria monocytogenes, Salmonella enterica ser. Typhimurium and Escherichia coli O157:H7) inoculated meat to non-inoculated beef fillets through meat mincing machine. Three different initial inoculum sizes $(3,5$, or 7 $\log \mathrm{CFU} / \mathrm{g}$ ) were tested and the inoculated beef fillets passed through meat mincing machine and then, six non-inoculated beef fillets passed in sequence through the same mincing machine without sanitation. As the result, all noninoculated beef fillets were contaminated through mincing with all pathogens, regardless the inoculum levels used. This observation also showed us that mincing machines are important contamination points.

Table 3. Mean and min-max of ATP values (RLU/100 $\left.\mathrm{cm}^{2}\right)$ and indicator bacteria counts $\left(\mathrm{CFU} / 100 \mathrm{~cm}^{2}\right)$ for food contact surfaces in all butcher shops

\begin{tabular}{|l|l|l|l|l|l|l|l|l|l|}
\hline \multirow{2}{*}{ Control Points } & \multirow{2}{*}{} & \multicolumn{2}{|c|}{ Visit 1 } & \multicolumn{2}{c|}{ Visit 2 } & \multicolumn{2}{c|}{ Visit 3 } & \multicolumn{2}{c|}{ Visit 4 } \\
\cline { 2 - 11 } & $\mathbf{N}$ & Mean & Min-max & Mean & Min-max & Mean & Min-max & Mean & Min-max \\
\hline Cutting board ATP & 10 & 9928 & $388-24334$ & 14778 & $1272-48011$ & 5679 & $11-19793$ & 9668 & $331-46011$ \\
\hline Cutting board TMAB & 10 & 3 & $2,11-3,58$ & 3,1 & $2,62-3,39$ & 2,82 & $1,6-3,35$ & 2,75 & $1,62-3,23$ \\
\hline Cutting board C & 10 & 0,85 & $0,3-1,6$ & 0,6 & $0-1,48$ & 1,56 & $0-1,6$ & 0,78 & $0-1,7$ \\
\hline & & & & & & & & & \\
\hline Knife ATP & 10 & 2496 & $17-9729$ & 2816 & $13-18197$ & 472 & $35-870$ & 887 & $88-2562$ \\
\hline Knife TMAB & 10 & 2,1 & $0,3-2,58$ & 2,75 & $1,38-3,4$ & 2.31 & $1,2-2,95$ & 1,86 & $1,15-2,18$ \\
\hline Knife C & 10 & 0 & $0-0,7$ & 0,3 & $0-1,36$ & 0.48 & $0,3-1,32$ & 1,18 & $1,65-2$ \\
\hline & & & & & & & & & \\
\hline $\begin{array}{l}\text { Mincing machine } \\
\text { ATP }\end{array}$ & 10 & 12606 & $64-63843$ & 1334 & $28-9706$ & 1155 & $16-2611$ & 1674 & $10-12407$ \\
\hline $\begin{array}{l}\text { Mincing machine } \\
\text { TMAB }\end{array}$ & 10 & 2,35 & $1,28-2,96$ & 2,62 & $1,65-3,14$ & 2,51 & $1,79-2,97$ & 2,02 & $1,56-2,41$ \\
\hline Mincing machine C & 10 & 1,04 & $0-1,95$ & 0,48 & $0,7-1,4$ & 0,48 & $0-1,34$ & 1,04 & $0-2$ \\
\hline
\end{tabular}

It is stated that $60 \%$ of the staff working in the food establishments do not wash their hands correctly and $25-40 \%$ of the food-borne diseases originate from those working in food processing and food service (Temelli et al., 2005). In our study, microbiological samples from the hands of staffs working in the butcher shops, coliform bacteria were mostly negative and all were under the defined critical limits (Table 2). No measurements were detected negative for Staphylococci but no one was identified as $S$. aureus. However, many researchers detected $S$. aureus and should be accepted as a main risk for food handlers' hand hygiene. For instance, Lues and Van Tonder (2007) detected S.aureus as 88\% and Ayçiçek (2004) 95\%, Shojaei et al., (2006) $12,6 \%$, Gorman et al., (2002) 4,5\% on the hands of food handlers in different food production areas. Staphylococci counts on staffs' hands range from min $1,7 \log _{10} \mathrm{CFU} /$ hand to $\max 3,26 \quad \log _{10} \mathrm{CFU} /$ hand (Table 4). Employee hygiene and particularly good hand hygiene, is crucial in reducing the contamination of food and minimizing the risk of food-borne 
illnesses (Rediers et al., 2008). EC Commission Regulation 2073/2005 on microbiological criteria for foodstuffs is directed at food operators and provides food safety and process hygiene criteria (Lehto et al., 2011). As Barker et al., (2004) mentioned; fingers contaminated by an environmental surface can transfer viruses to up to seven clean surfaces. In the study of Temelli et al., (2005), the hygienic status of personnel hands working in meat cutting units was evaluated. TMAB, coliform bacteria, $E$. coli, Enterobacteriaceae, staphylococci, coagulase positive staphylococci and yeast and mold were enumerated. Average coliform bacteria counts were found as $10^{3}\left(3 \log _{10}\right)$ $\mathrm{CFU} / \mathrm{ml}$ on the personnel hands working in butcher shops and E. coli was found in the hands of personnel working in butcher shops as $37,5 \%$. While mean staphylococci counts $(\mathrm{CFU} / \mathrm{ml})$ of personnel hands were found as $10^{4}\left(4 \log _{10}\right)$, coagulase positive staphylococci were detected as $40 \%$ in butcher shops.

In food plants ambient air contains many substances, which are present in free form or connected to the substances called bioaerosol. There are many sources for air-borne microorganisms such as employees, ventilation, air conditioning, packaging material, entering air from outside and etc. Microbial factors include bacteria, yeasts, molds and viruses. Airborne microorganisms can be found on solid particles such as dust or in aerosol droplets, besides in the form of single organisms resulting from evaporation of water droplets or can occur with the development of certain types of molds (Özer and Kesenkaş, 2015). According to the air microbiological load measurement results; none of the butcher shops' cold storage rooms exceed the defined limit $\left(3 \log _{10} \mathrm{CFU} / \mathrm{m}^{3}\right)$ for mold and yeast counts. These cold storage rooms were the places where naked carcasses and un-wrapped meat products were kept. Because of that, obtaining low level of mold and yeast loads is satisfying result in terms of food safety and hygienic storage conditions. Asefa et al., (2010) investigated the patterns of fungal growth on dry-cured meat products, identified the important sources and factors of contamination. They collected 642 samples from the meat, production materials, room installations and indoor and outdoor air of the production facility. Standard mycological isolation and identification procedures were followed. Totally, 901 fungal isolates were obtained; of which $57 \%$ were molds while $43 \%$ were yeast. In our study we haven't detected mold and yeast load over the limits but such studies like Asefa et al., performed should be conducted in order to make risk evaluation for air microbiological load.

Table 4. Mean and min-max of indicator bacteria counts (CFU/ hand) for food handlers' hands and air of cold storage rooms $\left(\mathrm{CFU} / \mathrm{m}^{3}\right)$ in all butcher shops

\begin{tabular}{|l|l|l|l|l|l|l|l|l|l|}
\hline \multirow{2}{*}{ Control Points } & \multirow{2}{*}{$\mathbf{N}$} & \multicolumn{2}{|c|}{ Visit 1 } & \multicolumn{2}{c|}{ Visit 2 } & \multicolumn{2}{c|}{ Visit 3 } & \multicolumn{2}{c|}{ Visit 4 } \\
\cline { 3 - 11 } & & Mean & Min-max & Mean & Min-max & Mean & Min-max & $\begin{array}{c}\text { Mean } \\
\text { Min- } \\
\text { max }\end{array}$ \\
\hline Hands ST & 10 & 2,76 & $2,28-3,23$ & 2,76 & $2,26-3,15$ & 2,8 & $2,18-3,26$ & 2,3 & $1,7-2,57$ \\
\hline Hands C & 10 & 0 & $0-0,6$ & $\mathrm{Nd}$ & $\mathrm{Nd}$ & 0,3 & $0,95-1$ & 0,3 & $0-1,2$ \\
\hline & & & & & & & & & \\
\hline $\begin{array}{l}\text { Storage rooms'air } \\
\text { MY }\end{array}$ & 10 & 1,566 & $1,41-1,76$ & 1,61 & $1,43-1,89$ & 1,88 & $1,28-2,14$ & 1,72 & $1,45-2$ \\
\hline
\end{tabular}

ST: Staphylococci; C: Coliform bacteria; MY: Molds and yeasts; TMAB: Total mesophile aerobe bacteria; Nd: not detected. Microbiological results presented as $\log _{10}$ values 
Table 5. Calculated score and the GHP status of all butcher shops depending on scoring system

\begin{tabular}{|l|l|l|}
\hline $\begin{array}{l}\text { Pilot butcher } \\
\text { shops }\end{array}$ & $\begin{array}{l}\text { *Calculated } \\
\text { score }\end{array}$ & $\begin{array}{l}\text { Hygiene } \\
\text { status }\end{array}$ \\
\hline Bs 1 & 74 & Good \\
\hline Bs 2 & 80 & Good \\
\hline Bs 3 & 74 & Good \\
\hline Bs 4 & 52 & Bad \\
\hline Bs 5 & 72 & Good \\
\hline Bs 6 & 60 & Bad \\
\hline Bs 7 & 68 & Acceptable \\
\hline Bs 8 & 64 & Bad \\
\hline Bs 9 & 76 & Good \\
\hline Bs10 & 100 & Good \\
\hline
\end{tabular}

Table 5 presents the calculated scores of each butcher shops depending on the developed scoring system and the GHP status according to the scores. 6 of $10(60 \%)$ butcher shops had the score over 68 which means "good" hygienic status. 3 butcher shops were defined as to apply "bad" hygiene practice and 1 of them was obtained to be "acceptable". Those results and also our evaluations on visual inspection that we have made during the visits showed us that, most of the selected butcher shops had satisfied level of GHP. The visual inspection is a method is still widely used to assess the level of cleanliness (Carrascosa et al., 2012; Tebbutt et al., 2007). Parallel to the goal in our study, Barril et al., (2019) collected the samples to investigate indicator microorganisms from the meat contact surfaces and characterized a checklist for the hygienic-sanitary risk of the butcher shops based on the quantitative results. They concluded that, risk quantification was useful to identify failures in different areas of the butcher shops. Leotta et

\section{Conclusions}

As a result; although it is stated that it has been cleaned, it was seen that microbiological load is high, especially when cutting boards are not cleaned well, organic pollution and indicator microorganisms as high as that can create a risk for public health, and that was similar for meat mincing machines. It has been determined air mycological load of cold storage rooms is acceptable but monitoring and air disinfection should be periodically carried out in the cold air al., (2016) performed a comprehensive evaluation of risk (before training and after training actions) in butcher shops of Buenos Aires, Argentina under a pilot program called "Healthy Butcher Shops". During this study, risk was quantified on a 1-100 scale as high-risk (1-40), moderate-risk (41-70) or low-risk (71100). A total of 172 raw ground beef and 672 environmental samples were collected from 86 butcher shops during the evaluation (20102011) and verification (2013) stages of the study. Risk quantification resulted in $43(50,0 \%)$ high-risk, 34 (39,5\%) moderate-risk, and nine $(10,5 \%)$ low-risk butcher shops before the training and 19 (22,1\%) high-risk, $42(48,8 \%)$ moderate-risk and $25(29,1 \%)$ low-risk butcher shops after the training programs. As the conclusion of the program, they reported that risk quantification was useful to identify the hazards in butcher shops and the reduction of microbiological load in ground beef and the environment was possible.

stores where the non-packaged products are stored. As a result of risk scoring system, most of the $(60 \%)$ butcher shops were observed to be in good position in terms GHP.

\section{References}

Aksu, F. Y., Altunatmaz, S. S., Harun, U. R. A. N., \& Altiner, D. D. (2017). hipermarketlerde gıda temas yüzeylerinin mikrobiyolojik özellikleri ve satış personelinin el hijyeni düzeyi. Erciyes 
Üniversitesi Veteriner Fakültesi Dergisi, 14(1), 17-23.

Aksu, H. \& Kaya, İ. (2000). Gida sanayinde personel hijyeni. Glda Mühendisliği Dergisi, 3(7), 15-9.

Asefa, D. T., Kure, C. F., Gjerde, R. O., Omer, M. K., Langsrud, S., Nesbakken, T., \& Skaar, I. (2010). Fungal growth pattern, sources and factors of mould contamination in a dry-cured meat production facility. International Journal of Food Microbiology, 140(2-3), 131-135.

Ayçiçek, H., Aydoğan, H., Küçükkaraaslan, A., Baysallar, M., \& Başustaoğlu, A. C. (2004). Assessment of the bacterial contamination on hands of hospital food handlers. Food Control, 15(4), 253-259.

Barker, J., Vipond, I. B., \& Bloomfield, S. F. (2004). Effect of cleaning and disinfection in reducing the spread of Norovirus contamination via environmental surfaces. Journal of Hospital Infection, 58,42-49.

Barril, P. A., Soto, S. A., Jaureguiberry, M. V., Gottardi, G., Bascur, I., Leotta, G. A., \&Oteiza, J. M. (2019). Microbiological risk characterization in butcher shops from the province of Neuquen, Patagonia Argentina. LWT Food Science and Technology, 107, 35-40.

Barros, M. A., Nero, L. A., Silva, L. C., d'Ovidio, L., Monteiro, F. A., Tamanini, R., ... \& Beloti, V. (2007). Listeria monocytogenes: Occurrence in beef and identification of the main contamination points in processing plants. Meat Science, 76(4), 591-596.

Calvert, R. M., Hopkins, H. C., Reilly, M. J., \& Forsythe, S. J. (2000). Caged ATP-an internal calibration method for ATP bioluminescence assays. Letters in Applied Microbiology, 30(3), 223-227.
Carrascosa, C., Saavedra, P., Millán, R., Jaber, J. R., Pérez, E., Grau, R., ...\&Sanjuán, E. (2012). Monitoring of cleanliness and disinfection in dairies: Comparison of traditional microbiological and ATP Bioluminescence methods. Food Control, 28(2), 368-373.

Çetin, Ö., Kahraman, T., \& Büyükünal, S. K. (2006). Microbiological evaluation of food contact surfaces at red meat processing plants in Istanbul, Turkey. Italian Journal of Animal Science, 5(3), 277-283.

Chen, J. (2000). ATP bioluminescence: a rapid indicator for environmental hygieneand microbial quality of meats. Dairy, Food and Environmental Sanitation, 20,617-620.

Da Cruz, A. G., Cenci, S. A., \& Maia, M. C. (2006). Quality assurance requirements in produce processing. Trends in Food Science \& Technology, 17(8), 406-411.

da Silva, D. A. L., Dias, M. R., Cossi, M. V. C., de Castilho, N. P. A., Camargo, A. C., \& Nero, L. A. (2016). Hygiene and safety in the meat processing environment from butcher shops: microbiological contamination and Listeria monocytogenes. Journal of Food Protection, 79(4), 628-634.

Duffy, S., \& Schaffner, D. W. (2002). Monte Carlo simulation of the risk of contamination of apples with Escherichia coli O157: H7. International Journal of Food Microbiology, 78(3), 245-255.

EFSA and ECDC (European Food Safety Authority and European Centre for Disease Prevention and Control) (2016). The European Union summary report on trends and sources of zoonoses, zoonotic agents and food-borne outbreaks in 2015. EFSA Journal, 14(12), 4634, 231 pp.

Fidan, F., \& Ağaoğlu, S. (2004). Ağrı bölgesinde bulunan lokantaların hijyenik durumu üzerine araştırmalar. Yüzüncü $Y l l$ 
Üniversitesi Veteriner Fakültesi Dergisi, 15(1), 107-114.

Garedew, L., Hagos, Z., Zegeye, B., \& Addis, Z. (2016). The detection and antimicrobial susceptibility profile of Shigella isolates from meat and swab samples at butchers' shops in Gondar town, Northwest Ethiopia. Journal of Infection and Public Health, 9(3), 348-355.

Ghafir, Y., China, B., Dierick, K., De Zutter, L., \& Daube, G. (2008). Hygiene indicator microorganisms for selected pathogens on beef, pork, and poultry meats in Belgium. Journal of Food Protection, 71(1), 35-45.

Gorman, R., Bloomfield, S., \& Adley, C. C. (2002). A study of cross-contamination of food-borne pathogens in the domestic kitchen in the Republic of Ireland. International Journal of Food Microbiology, 76(1-2), 143-150.

Kymäläinen, H. R., Kuisma, R., Määttä, J., \& Sjöberg, A. M. (2009). Assessment of cleanness of environmental surfaces in cattle barns and piggeries.

Lehto, M., Kuisma, R., Määttä, J., Kymäläinen, H. R., \&Mäki, M. (2011). Hygienic level and surface contamination in fresh-cut vegetable production plants. Food Control, 22(3), 469475.

Leotta, G. A., Brusa, V., Galli, L., Adriani, C., Linares, L., Etcheverria, A., ... \& Signorini, M. (2016). Comprehensive evaluation and implementation of improvement actions in butcher shops. PLoS One, 11(9).

López-Campos, G., Martínez-Suárez, J. V., Aguado-Urda, M., \& López-Alonso, V. (2012). Detection, identification, and analysis of foodborne pathogens. In Microarray detection and characterization of bacterial foodborne pathogens (pp. 13-32). Springer, Boston, MA.
Luck, H. \& Gavron, H. (1990). The microbiology of milk products. In: Robinson RK, editor. Dairy microbiology. London, Elsevier Applied Science Publishers; 1990. p.345-392.

Lues, J. F. R., \& Van Tonder, I. (2007). The occurrence of indicator bacteria on hands and aprons of food handlers in the delicatessen sections of a retail group. Food Control, 18(4), 326-332.

Moore, G., \& Griffith, C. (2002). A comparison of traditional and recently developed methods for monitoring surface hygiene within the food industry: an industry trial. International Journal of Environmental Health Research, 12(4), 317-329.

Mulvey, D., Redding, P., Robertson, C., Woodall, C., Kingsmore, P., Bedwell, D., \& Dancer, S. J. (2011). Finding a benchmark for monitoring hospital cleanliness. Journal of Hospital Infection, 77(1), 25-30.

Papadopoulou, O. S., Chorianopoulos, N. G., Gkana, E. N., Grounta, A. V., Koutsoumanis, K. P., \& Nychas, G. J. (2012). Transfer of foodborne pathogenic bacteria to non-inoculated beef fillets through meat mincing machine. Meat Science, 90(3), 865-869.

Rao, D. N., \& Ramesh, B. S. (1992). The microbiology of sheep carcasses processed in a modern Indian abattoir. Meat Science, 32(4), 425-436.

Rediers, H., Claes, M., Kinnerk, R., Peeters, L., \& Willems, K. (2008). Hand hygiene: resolving an enigma?. Food Protection Trends, 28, 568-584.

Salo, S., Ehavald, H., Raaska, L., Vokk, R., \& Wirtanen, G. (2006). Microbial surveys inEstonian dairies. LWT Food Science and Technology, 39(5), 460-471.

Scott, E. (2003). Food safety and foodborne disease in 21 st century homes. Canadian 
Journal of Infectious Diseases, 14(5), 277280.

Shama, G., \& Malik, D. J. (2013). The uses and abuses of rapid bioluminescence-based ATP assays. International Journal of Hygiene and Environmental Health, 216(2), 115-125.

Shojaei, H., Shooshtaripoor, J., \& Amiri, M. (2006). Efficacy of simple hand-washing in reduction of microbial hand contamination of Iranian food handlers. Food Research International, 39(5), 525-529.

Tebbutt, G., Bell, V., \& Aislabie, J. (2007). Verification of cleaning efficiency andits possible role in programmed hygiene inspections of food businesses undertaken by local authority officers. Journal of Applied Microbiology, 102, 1010-1017.

Temelli, S., Şen, M. C., \& Anar Ş. (2005). Et parçalama ünitelerinde ve beyaz peynir üretiminde çalışan personel ellerinin hijyenik durumunun değerlendirilmesi. Uludağ Üniversitesi Veteriner Fakültesi Dergisi, 24(1-2-3-4), 75-80.

Torso, L. M., Voorhees, R. E., Forest, S. A., Gordon, A. Z., Silvestri, S. A., Kissler, B., Schlackman, J., Sandt, C. H., Toma, P., Bachert, J., Mertz, K. J., \& Harrison, L. H. (2015). Escherichia coli O157:H7 outbreak associated with restaurant beef grinding. Journal of Food Protection, 78, 1272-1279.

Özer, E., \& Kesenkaş, H. (2015). Süt İşletmelerinde Hava Kalitesi ve Önemi. Academic Food Journal/Akademik GIDA, 13(1).

Vilar, M. J., Rodríguez-Otero, J. L., Diéguez, F. J., Sanjuán, M. L., \& Yus, E. (2008). Application of ATP bioluminescence for evaluation of surface cleanliness of milking equipment. International Journal of Food Microbiology, 125(3), 357-361.

\section{Acknowledgment}

This study was conducted in cooperation with TRNC Degirmenlik Municipality Directorate of Veterinary Affairs, Nicosia. 